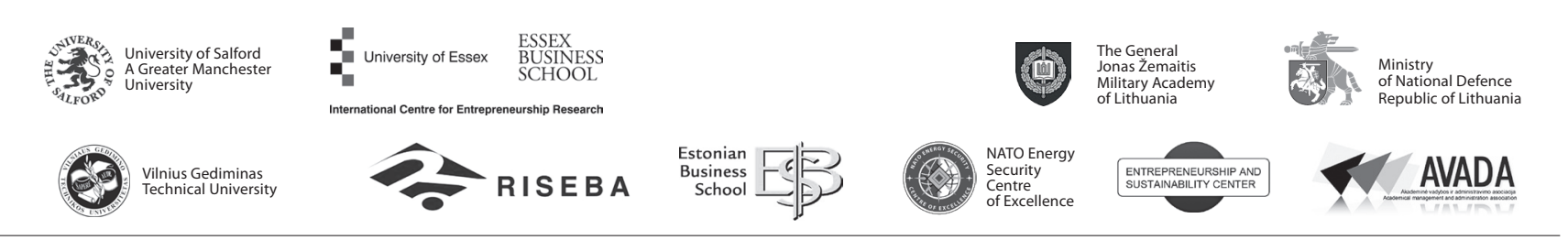

\author{
JOURNAL OF SECURITY AND SUSTAINABILITY ISSUES \\ ISSN 2029-7017 print/ISSN 2029-7025 online \\ 2017 December Volume 7 Number 2 \\ https://doi.org/10.9770/jssi.2017.7.2(6)
}

\title{
THE ROLE OF LEADERSHIP IN MOTIVATING EMPLOYEES IN A TRADING COMPANY
}

\author{
Adriana Grenčíková 1 , Jūratė Guščinskienė², Jana Španková ${ }^{3}$ \\ ${ }^{1,3}$ Alexander Dubcek University of Trencin, Faculty of Social and Economic Relations, Slovak Republic \\ ${ }^{2}$ The General Jonas Žemaitis Military Academy of Lithuania, Šilo Str. 5A, Vilnius LT-10322, Lithuania \\ E-mails: ' $a d r i a n a . g r e n c i k o v a @ t n u n i . s k ; ~ 2 j u r a t e . g u s c i n s k i e n e @ l k a . l t$ \\ 3jana.spankova@tnuni.sk
}

Received 18 March 2017; 25 September 272017

\begin{abstract}
Effective employee motivation needs leaders who are able to formulate visions of incentive programs and who have positive influence on employees. Leaders are able to analyse the environment regarding the level of motivation, barriers to motivation and are able to develop an effective motivation system. A motivation system refers to a system illustrating basic motives, motivation preferences, intentions and priorities, incentives being applied and their effects. The authors of the paper attempt to assess the level of employee motivation in a trading company and its relation to work performance. The research was conducted in the months of September December 2016 and 213 respondents were asked to fill out the questionnaire. A Pareto chart was used illustrate the research results.
\end{abstract}

Key words: motivation, work performance, leader, managing work, system of motivation, motivation strategy

Reference to this paper should be made as follows: Grenčíková, A.; Guščinskienė, J.; Španková, J. 2017. The role of leadership in motivating employees in a trading company, Journal of Security and Sustainability Issues 7(2):247-255.

https://doi.org/10.9770/jssi.2017.7.2(6)

JEL codes: M51

\section{Introduction}

When managing work performance, it is important to bear in mind that the primary purpose of all businesses is to maximize profits. There are two basic ways of making a profit, related both to input and output. Thus, higher profits or measurable success of a trading company can be achieved by lowering input costs or increasing output. The study addresses the input cost area, in particular employee motivation. Employee work performance is connected to job-related competence, objective working conditions in an organization and employee motivation (Vetráková, 2011, p.153; Lepir, et al., 2016; Caracota and Mitovski, 2014; Ristic, et al., 2017). Motivated employees are one of the key determinants for an organization to succeed. (Nemeckova, 2017; Baard, et al., 2004; Mentel et al., 2016). To motivate employees means to get them work as effectively as they can. Motivational programs can greatly increase the return on investments related to human resource development (Vojtovič 2008, p.117; Prakapavičiūtè, Korsakienè, 2016, Sirková, et al., 2016).

It is neither an easy nor fast process to achieve the required employee motivation (Myšková et al., 2016). High performance does not only depend on motivation (Hitka and Balážová, 2015; Kaźmierczyk, Aptacy, 2016), but also on the level of competence to perform the job. 
Having specific abilities, knowledge and skills may also be a kind of motivation. Thus, motivation and competence constitute the two basic groups of subjective personal determinants of employee performance. (Kuvaas et al., 2017). A system of motivation comprises all the motivation-related materials and documents affecting the performance of an organization. The system of motivation is to systematically influence and motivate individuals, groups and teams. The system of motivation includes a motivation strategy and a set of incentive programs (Becchetti, 2013). A motivation strategy, developed under personnel strategy, must be aligned with the overall strategy of an organization (Parker at al., 2017). A well-designed motivation strategy should have two missions, i.e. to support achieving the goals of an organization as well as employee personal goals.

\section{Purpose and methods}

The purpose of the study was to analyse the questionnaire data, to assess the level of employee motivation in a trading company and find out what impact it has on employee performance. First, a company profile was established to find the relevant information about the company that, if needed, could be benchmarked with other relevant companies. Next, the forms and methods of motivation used in the company were identified. Finally, a questionnaire was developed and filled in by a selected number of respondents. The questionnaire survey was to find out what motivates the employees of the company best, and whether the system of motivation is effective. The online questionnaire was distributed to respondents working in stores in Slovakia under an operating division. The questionnaire was developed online using an application which made the work easier and faster. In order to ensure objectivity and privacy of respondents, responses were provided anonymously. 54 respondents chose to fill out a survey online. Due to length limits, only the key findings are highlighted in the paper.

Various statistical methods to treat and evaluate questionnaire data were utilised, such as for instance contingency tables and a Pareto chart. To illustrate the data obtained, graphs were used. In the paper, the methods of analysis, synthesis and deduction were employed to draw conclusions and make recommendations for the company. The real name of the company was not used as the company chose to remain anonymous.

\section{Results}

The interpretation of results followed the three hypotheses formulated. The survey process includes evaluating survey questions graphically as well as evaluating hypotheses.

H1: Employees are aware of the existence of the system of motivation. Employees find motivation important.

Respondents were asked whether they find motivation important. It was found that $89 \%$ of respondents found motivation of great significance, $11 \%$ somewhat agreed that motivation is of great value. It follows that motivation at work is important for all employees, regardless of age, job title or education. Well-known authors dealing with the issue of motivation also share the same opinions ( Graph 1). 


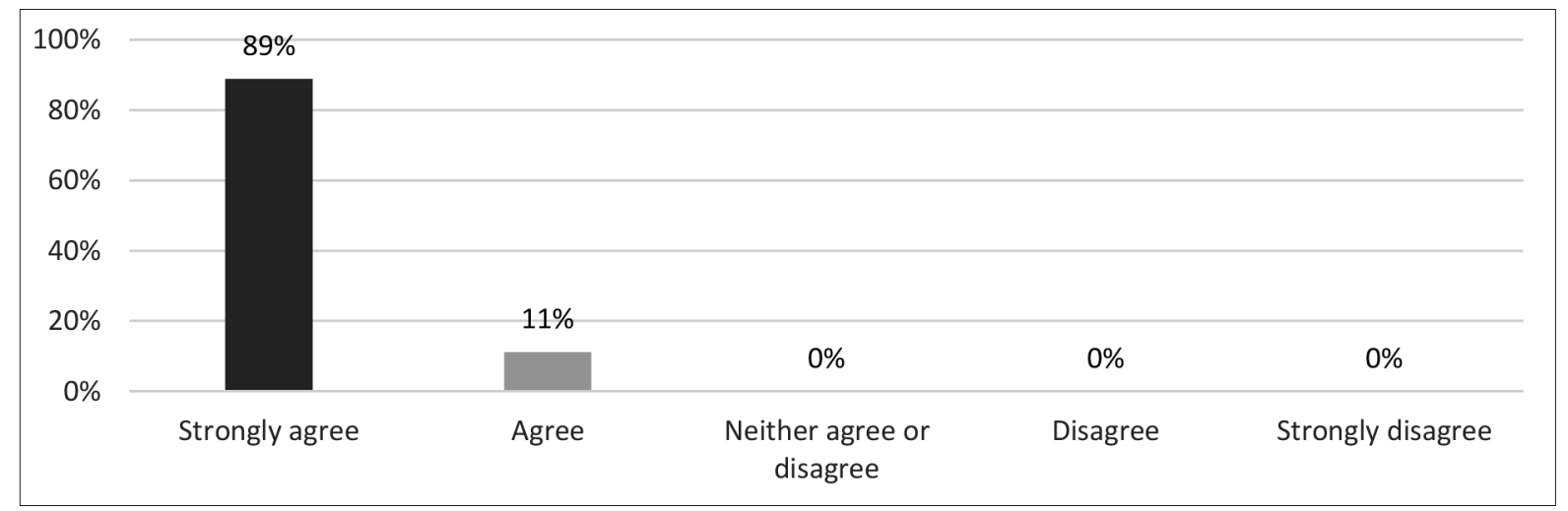

Graph 1. Importance of motivation for employees

Source: Authors' own based on the questionnaire responses

The next question was to find whether the respondents are familiar with the employee motivation program. It was found that $67 \%$ of employees know that there is an employee motivation program in place and $26 \%$ of employees are rather familiar with the program. There are no respondents being not familiar with the program or not interested in the program (Graph 2).

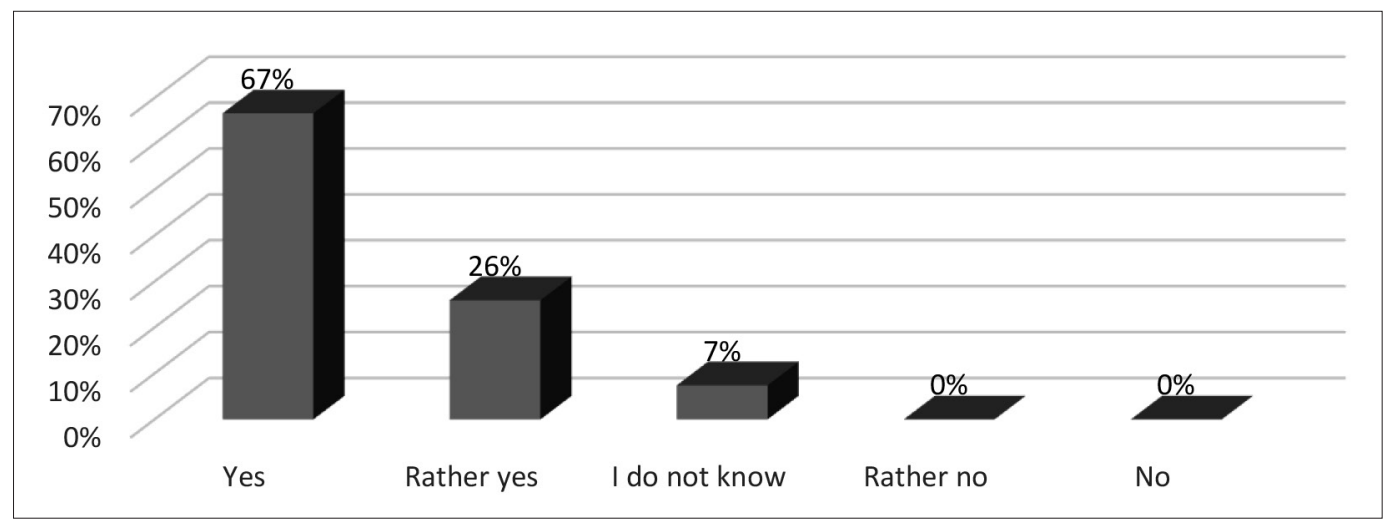

Graph 2. Familiarity with the motivation system

Source: Authors' own based on the questionnaire responses

Despite the fact that this question was answered almost unambiguously, the responses were looked at in more detail. For the purpose of comparison, an additional factor related to the structure of the respondents was considered in order to find dependency of responses on a job position. To provide a higher informative value, a share expressed as a percentage (not in absolute numbers) was used, since each job position has a different number of employees. The data was visualized in a graph showing the dependence between a job position and an awareness of the motivation program. $83 \%$ of store managers, who should be the store leaders, are familiar with the motivation program.

Their familiarity with the motivation program should, however, be $100 \%$. The familiarity with the motivation program goes down to $27 \%$ in part-time workers. Low familiarity with the existence of the motivation program in part-time workers is understandable, yet the percentage of the store leaders being aware of the motivation program in place, even though the highest, is not considered sufficient. One of the tasks of a leader is to ensure that his/her subordinates have all the required information and knowledge. If, however, the store leaders themselves are not familiar with the motivation program or do not have sufficient information about it, they cannot work effectively with their employees and/or use the program to increase their work performance. Thus, the survey results support the hypothesis. 
H2: Salary/Financial methods of motivation are seen as the most effective by employees.

Salary is the most important motivator according to several authors (Pop, 2016; Gunawan and Amalia, 2015; Blašková, et al., 2017). In today's society, money is needed to satisfy our basic and other needs and wants, and money is the main reason for most people to go to work. This fact supports the assumption that employees are mostly motivated by pay. Therefore, it is also assumed that pay is considered to be the most effective way to manage employee work performance. In the survey, respondents were asked what motivates them best at work. They were provided with five response options, such as salary, work as an activity, working time, workplace relationships, and treatment of employees by a superior. Out of all fifty-four employees, $41 \%$ consider the salary as the most important factor in employee motivation. On the one hand, the finding confirmed our assumptions, but on the other hand a higher percentage was expected.

Other motivating factors include work as an activity (22\%), relations at the workplace $(17 \%)$, treatment of employees by a superior (15\%) and the least important motivating factor was found to be hours of work $(5 \%)$. Compared with the previous questions, however, the responses are more evenly distributed and each option "found its own respondent", which shows that motivators vary from an employee to an employee. The result obtained is convincing, though not fully. Therefore, salary as the key motivator was analysed in terms of job positions. The graph below shows in detail the individual motivating factors broken down by job positions (Graph 3).

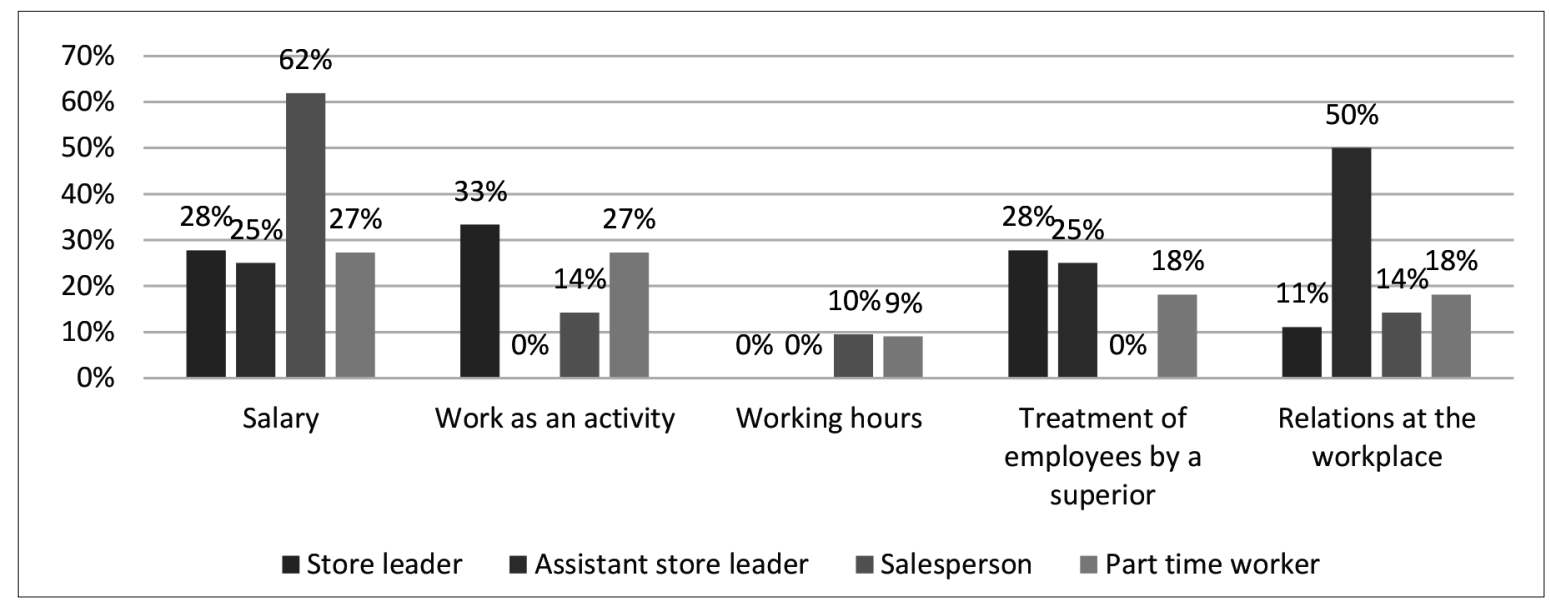

Graph 3. Motivating factors by job positions

Source: Authors' own based on the questionnaire responses

Apparently, money is not the primary motivating factor for all job positions. For instance, $66 \%$ of salespeople are motivated by money. Thus, other response options were less likely to be chosen, for instance treatment of employees by a superior was not selected by any sales person. Concerning the store leaders, salary is the third motivating factor along with the treatment of employees by a superior $(28 \%)$. Store leaders consider the work as an activity as a primary motivator (33\%) which indicates that they are the people engaged at work with good work habits and work experience. This is supported by the fact that no store manager selected the response option of working time.

The relationship between motivation and age was also examined (cf. the graph below). There are four age groups: to 25 years of age, to 35 years of age, to 45 years of age, and to 60 years of age. Compared to the overall results, a distinct difference was found in employees in the age group to 25 years. For them, the key motivating factor is salary (50\%). They are least motivated by the work itself. At the same time, they are the only for whom the hours of work are a priority (Graph 4). 


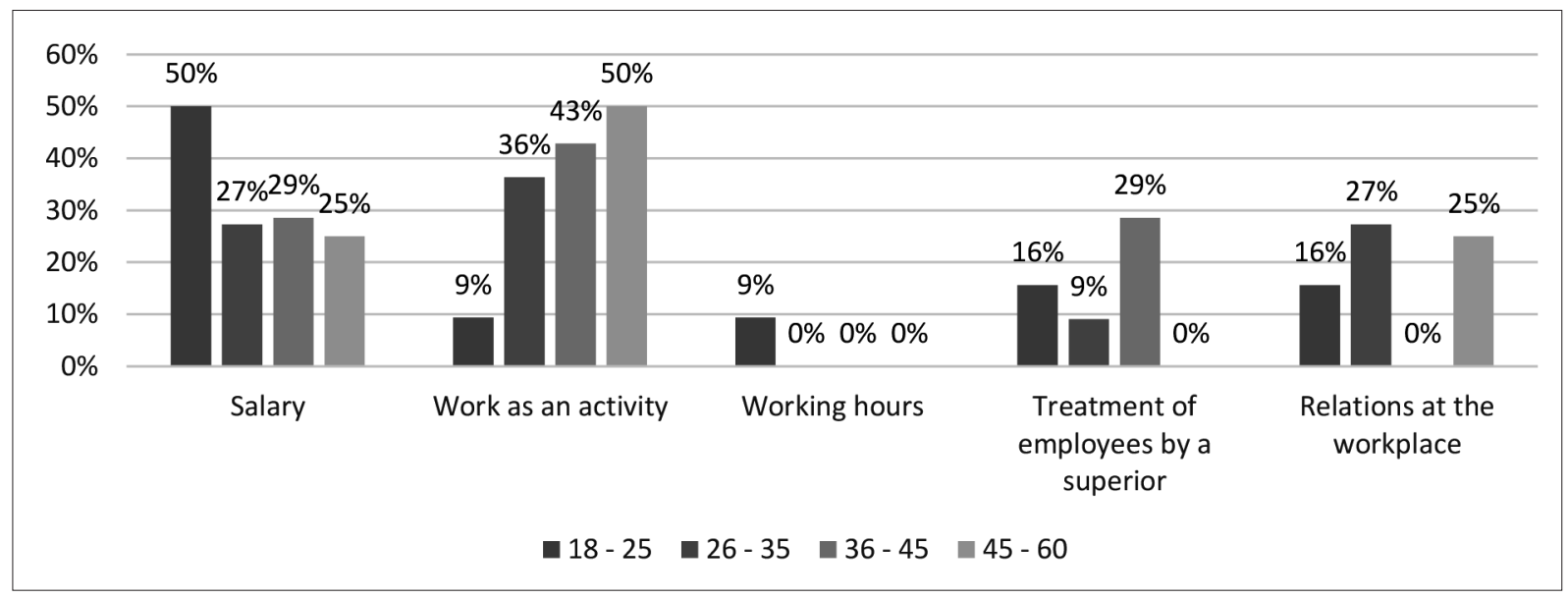

Graph 4. Motivating factors by age

Source: Authors' own based on the questionnaire responses

The two graphs above illustrated the marked differences regarding the employee motivation preferences in terms of job positions and age. When making the first graph, it seemed that there will be no difficulty to support the hypothesis. After a more detailed analysis, the outcomes are not that clear. Since the given hypothesis addresses only salary as a motivator, one more analysis was made with respect to the findings. To provide more in-depth results regarding motivating factors, two categories of employees were examined, such as salespeople in the age group to 25 years and store leaders above 35 years of age. The graph below illustrates their attitude to the motivating factors examined (Graph 5).

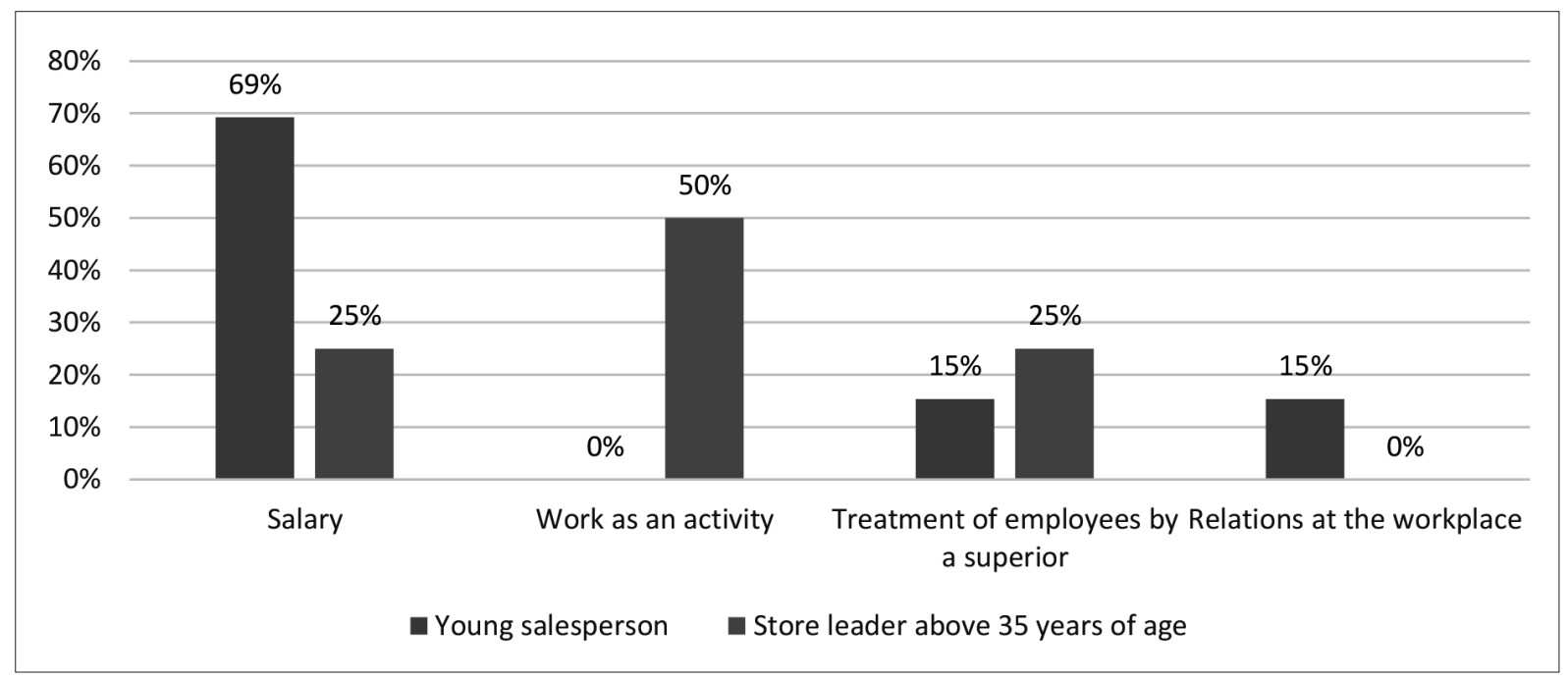

Graph 5. Motivating factors salesperson versus store leader

Source: Authors' own based on the questionnaire responses

The difference in preferences can clearly be seen in the graph. $69 \%$ of young salespeople give salary the top priority, whereas no priority is given to work as an activity. On the other hand, experienced store leaders with sound work habits mostly enjoy working $(50 \%)$, whereas only a quarter of them attach the highest importance to salary.

In the second hypothesis, it was assumed that salary/financial methods of motivation are seen as the most effective by employees. The findings, however, did not confirm our assumptions as work as an activity was still found to be motivating by $22 \%$ of respondents and relations at the workplace by $17 \%$ of respondents. There- 
fore, two more factors in relation to employee motivation were researched and analysed, such as job position and age. It was found that salary works as a key motivator only for certain categories of employees. Salary was ranked as a top motivator by young salespeople up to 25 years of age $(69 \%)$. As this age group is the most numerous, both in terms of the research sample and the overall age structure of the company employees, it has a considerable impact on the overall outcomes. Yet, the responses made by other age groups need to be considered as well. It follows from the results, that the hypothesis can be neither supported nor refuted with absolute certainty. It is true that salary is the key motivator, yet there are other motivating factors of importance. The only way to motivate employees to better performances is to apply an individual approach and have sufficient knowledge of the driving incentives that, as confirmed by the analysis, may vary from employee to employee. Leaders should be familiar with the all the factors that affect employee motivation.

H3: Motivating factors as well as the possibility of employee development are perceived positively by employees. This significantly affects their attitude to work and especially their work performance. Hypothesis testing was performed in two steps.

Motivating factors. The basic assumption was that a salary will be the key employee motivator. It, however, does not mean that other incentives are of no importance or can be disregarded. Therefore, the questionnaire comprised a series of questions to identify and analyse employee satisfaction with each motivating factor covered in the study. Respondents could choose an option on a scale of one to five: one meaning strongly dissatisfied, two meaning dissatisfied, three meaning a neutral response, four meaning satisfied and five meaning strongly satisfied.

First, respondents were asked whether they were satisfied with their salaries. As already mentioned, pay and money are considered to be the strongest incentive as supported by recognized authors and the research results presented. The graph below shows the results obtained (Graph 6).

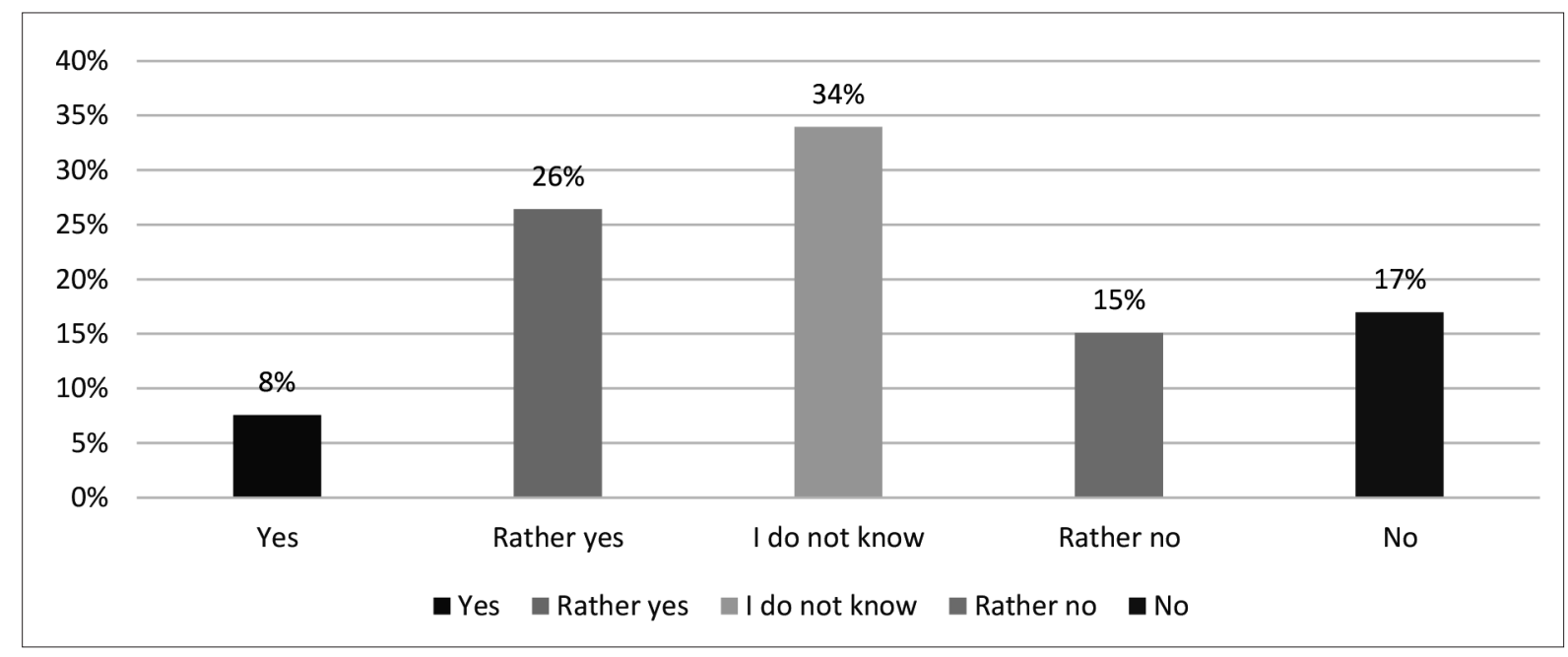

Graph 6. Satisfaction with salary

Source: Authors' own based on the questionnaire responses

The graph shows that the results were not as clear-cut as in previous analyses. For the sake of simplicity, instead of analysing five response options, only three of them were analysed. Dissatisfied/rather dissatisfied respondents and satisfied/rather satisfied respondents were put together and analysed. The research indicate that the percentage of satisfied, dissatisfied and neutral employees is almost the same. Thus, it was not possible to make any recommendations for the company in the area of employee motivation. Therefore, it was necessary to look at the issue from a different angle and in more detail, so the structure of the research sample was re-used. Out of all respondents, we focused only on those who said they were dissatisfied/rather dissatisfied with their salary $(32 \%)$. The respondents were then analysed by job positions and the duration of employment. The positions of 
salespeople and store managers were analysed as they cover the highest percentage of employees in the company - up to $79 \%$. Next, a graph showing the percentage of dissatisfied employees with regard to a job position and the duration of employment was developed. The results show that there is a marked dissatisfaction with salaries among store leaders $(50 \%)$, whereas the duration of employment is not relevant. The percentage of dissatisfied salespeople is lower (29\%), and a correlation between the job position and the duration of employment is obvious. Salespeople in probation period, along with those working in the company up to five years show approximately an average level of dissatisfaction. No dissatisfaction was found in the salespeople who completed a probation period and those employed in the company for a short period of time. Those who have been with the company for a long period of time showed 100\% dissatisfaction (Graph 7).

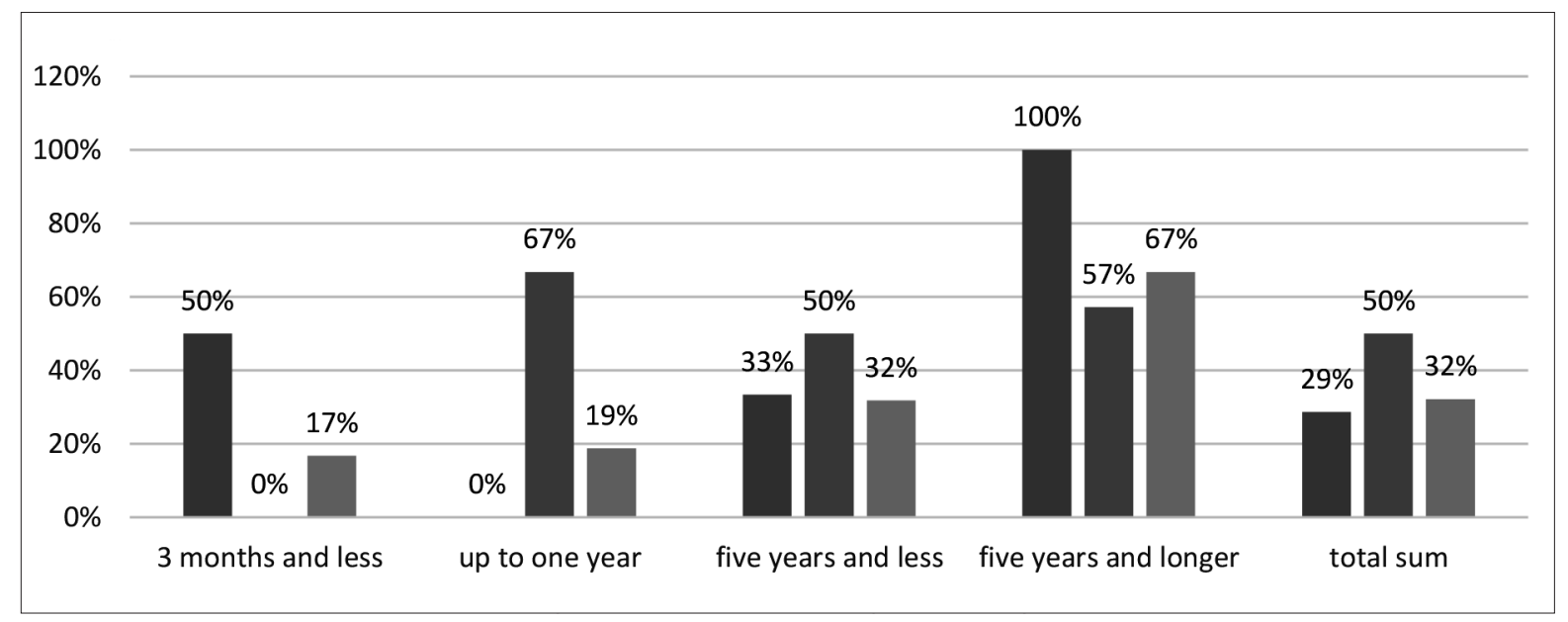

Graph 7. Satisfaction with salary by job positions and duration of employmen

Source: Authors' own based on the questionnaire responses

The results show clear differences, and at the same time reveal two areas that should be addressed. Although the level of dissatisfaction with salaries generally reaches an average value, it was found, after a detailed analysis, that store leaders show 50\% dissatisfaction with salaries. Store leaders are in the front-line management, and their duties include, among others, employee motivation in managing work performance. Even though it was found that salary is not the strongest motivator, it should be paid careful attention. With regard to the duration of the employment, employees being with the company for more than five years show the greatest dissatisfaction - up to $67 \%$, which is more than double the average. Those employees who have been with the company for a long time, who are familiar with all the procedures, and who are identified with corporate policies and culture should be the key asset to any company. Therefore, such a high level of dissatisfaction is considered as a potential problem in the long run.

\section{Conclusion}

All our recommendations as well as the level of motivation rely directly on the professionalism of store leaders and line managers. Companies may come up with a variety of incentives, may have an intricate corporate culture or above average payroll system. They, however, need people - leaders who will put them into practice, who will check their use and evaluate their benefits. The company under examination lacks a real leader whose functions also include the one of motivating peers and subordinates to higher performances.

It was found that the company uses predominantly internal sources to fill managerial positions. That means that store leaders were once hired for the position of salespeople or line managers were originally employed as store leaders or salespeople. This practice has many advantages, such as full knowledge of procedures, identification with the company values, high levels of loyalty, commitment and motivation. There are, however, several risks associated with the practice. A major risk is that managerial positions are filled with employees who do not have sufficient expertise and/or are not genuine leaders. Being highly effective at work, reliable and efficient at work 
does not automatically make the person a good leader. To perform the functions of a leader, one needs to have certain personality prerequisites and experience, which can be acquired by strong support and frequent feedback. A depersonalization problem arises when the manager does not realize that he/she is not performing the job but ensures it to be done. Based on the findings, it is deemed necessary to have an employee development program in place and follow it while preparing managerial employees. Prior to taking up a managerial position, they shall be able to apply managerial working tools, have essential knowledge of personality psychology and effective employee motivation. This can only be achieved through long-term preparation with the support of external sources, which would be hired to provide the required training. At the same time, it is required to monitor the work of managerial staff even after taking up positions, to regularly evaluate them, to give them constructive feedback and to continue to work on their development in management, organization and motivation.

\section{References}

Baard, P.P., Deci, E.L., Ryan, R.M. (2004). Intrinsic need satisfaction: A motivational basis of performance and well-being in two work settings. Journal of Applied Social Psychology. Volume 34, Issue 10, October 2004, Pages 2045-2068. ISSN: 00219029

Becchetti, L., Castriota, S., Tortia, E. C (2013). Productivity, wages and intrinsic motivations. Small business economics. Volume: 41 Issue: 2 Pages: 379-399. ISSN 0921-898X. https://doi.org/10.1007/s11187-012-9431-2

Blašková, M., Blaško, R., Rosak-Szyrocka, J., Ulewicz, R. (2017). Flexibility and variability of motivating employees and managers in Slovakia and Poland. Polish Journal of Management Studies, Volume: 15, Number: 1, Pages: 26-36. https://doi.org/10.17512/ pjms.2017.15.1.03

Caracota Dimitriu, M., Mitovski, A. (2014). Motivation of employees and organizational stress management. Quality - Access to Success. Volume 15, Issue 140, Pages 109-112. ISSN 15822559

Gunawan, H., Amalia, R. (2015). Wages and employees performance: The quality of work life as moderator. International Journal of Economics and Financial Issues. Volume 5, 28 July 2015, Pages 349-353. ISSN: 21464138.

Hitka, M., Balážová, Ž. (2015). The impact of age, education and seniority on motivation of employees. Business: Theory and Practice. Volume 16, Issue 1, 30 March 2015, Pages 113-120. ISSN 16480627. https://doi.org/10.3846/btp.2015.433

Kaźmierczyk, J.; Aptacy, M. (2016). The management by objectives in banks: the Polish case, Entrepreneurship and Sustainability Issues Vol. 4, No 2, pp. 146-158. https://doi.org/10.9770/jesi.2016.4.2(3)

Kuvaas, B., Buch, R., Weibel, A. , Dysvik, A., Nerstad, C.G.L. (2017). Do intrinsic and extrinsic motivation relate differently to employee outcomes? Journal of Economic Psychology. Volume 61, August 2017, Pages 244-258. ISSN: 01674870.: https://doi.org/10.1016/j. joep.2017.05.004

Lepir, L., Šćepović, D., Radonjić, A.R. (2016). Challenges of human resource management in the institutions for care of elderly people. IOP Conference Series: Materials Science and Engineering. Volume 200, Issue 1, 25 May 2017. ISSN 17578981. https://doi. org/10.1088/1757-899X/200/1/012030

Mentel, G.; Szetela, B.; Tvaronavičienė, M. (2017). Qualifications of managers vs. effectiveness of investment funds in Poland, Economics \& sociology, Vol. 9, iss. 2 (2016), Pages 126-137. https://doi.org/10.14254/2071-789X.2016/9-2/8

Myšková, R., Hitka, M., Lorincová, S., Balážová, Ž. (2016). Regional motivation differences of service sector employees in urban and rural areas in Slovakia. Scientific Papers of the University of Pardubice, Series D: Faculty of Economics and Administration. Volume 23, Issue 37, 2016, Pages 118-130. ISSN: 1211555X

Nemeckova, I. (2017). The role of benefits in employee motivation and retention in the financial sector of the Czech Republic. Economic Research-Ekonomska Istrazivanja. Volume: 30, Issue: 1 Pages: 694-704. ISSN 1331-677X. https://doi.org/10.1080/133167 7X.2017.1314827

Parker, S.L., Jimmieson, N.L., Amiot, C.E. (2017). The motivational mechanisms underlying active and high-strain work: consequences for mastery and performance. Work and Stress. Volume 31, Issue 3, 3 July 2017, Pages 233-255. ISSN: 02678373. https://doi.org/10.1 $080 / 02678373.2017 .1303551$

Prakapavičiūte, J.; Korsakienè, R. (2016). The investigation of human capital and investments into human capital: Lithuania in the context of the EU, Entrepreneurship and Sustainability Issues Vol. 3, No4, Pages 350- 367. https://doi.org/10.9770/jesi.2016.3.4(4)

Pop, M. (2016). Motivation and stimulation as a key instrument of employees stabilization. Knowlege for market USE 2016: OUR 
INTERCONNECTED AND DIVIDED WORLD. Pages: 364-368. Conference Conference: International Scientific Conference on Knowledge for Market Use 2016 - Our Interconnected and Divided World. Olomouc. ISBN 978-80-87533-14-7. Accession Number WOS:000389757500052

Ristic, M.R., Selakovic, M., Qureshi, T.M. (2017). Employee motivation strategies and creation of supportive work environment in societies of post-socialist transformation. Polish Journal of Management Studies, Volume: 15, Number 2, Pages: 205-216, https://doi. org/10.17512/pjms.2017.15.2.19

Sirková, M., Ali Taha, V., Ferencová, M. (2016). Management of HR processes in the specific contexts of selected area. Polish Journal of Management Studies, Volume: 13, Number: 2, Pages: 142-152. https://doi.org/10.17512/pjms.2016.13.2.14

Vojtovič, S. (2008). Riadenie personálnych činností v organizácii (Managing Personnel Activities in an Organization) . Bratislava: Iris, pp. 396. ISBN: 8089256174

Vetráková, M. A kol. (2011). Hodnotenie prínosu zamestnancov (Employee benefits assessment). Banská Bystrica: Univerzita Mateja Bela, Ekonomická fakulta, 2007. 192 s. ISBN 978-80-8083-537-8. 